\title{
: KARAKTERISTIKE PROGRAMA LOJALNOSTI U SEGMENTU MALOPRODAJE NAFTE I NAFTINIH DERIVATE NA TERITORIJI REPUBLIKE SRBIJE
}

\author{
Goran Dašić* \\ Visoka škola modernog biznisa, Beograd \\ Irena Petrušić \\ Fakultet za menadžment, Herceg Novi \\ Adriana Radosavac
}

Fakultet za primenjeni menadžment, ekonomiju i finansije, Beograd

Intenzivna konkurentska borba glavno je obeležje aktuelnog poslov-

nog okruženja. Pronalaženje načina da se kompanija, odnosno njena ponuda, izdiferencira na način koji će potrošačima pružiti veću vrednost danas je imperativ. Programi lojalnosti predstavljaju popularni marketinški alat čiji je primarni cilj stvaranje lojalnih potrošača i efikasno upravljanje odnosima sa njima.

U radu su prikazani aktuelni programi lojalnosti kompanija koje se bave maloprodajom nafte i naftinih derivate na tržištu Republike Srbije, njihova struktura i karakteristike.

Ključne reči: Iojalnost potrošača, satisfakcija potrošača, program lojalnosti, maloprodaja nafte i naftinih derivate

\section{Uvod}

isok stepen konkurentnosti, globalizacija, dinamične promene, neizvesnost samo su neke od karakteristika savremenog poslovnog okruženja. Odgovorni za kreiranje poslovnih strategija u kompanijama suočavaju se sa velikim izazovom pronalaženja modela diferenciranja koji će ih uzdvojiti od konkurencije i omogućiti im poslovni uspeh. Razvoj ključnih kompetencija, koje su srž diferencijacije, kompanije između ostalog temelje na inovacijama, tehnološkoj superiornosti, edukaciji i obuci zaposlenih, unapređenju komunikacije, zadržavanju i privlačenju novih potrošača sl.

Stvaranje zadovoljnih potrošača je svrha savremenog poslovanja. Kompanije često pribegavaju kombinovanju više elemenata kako bi stekle ključne kompetencije koje će potrošačima pružiti veću vrednost, odnosno viši novo satisfakcije. U teoriji marketinga odavno je poznao da zadovoljstvo - satisfakcija potrošača bitan uslov za stvaranje lojalnih potrošača, ali ne i dovoljan. Danas, stvaranje zadovoljnih potrošača je dug i neizve-

*Dr Goran Dašić, goran.dasic@mbs.edu.rs 
stan proces, a samim tim lojalnost istih se dovodi u pitanje. Lojalnost nije glavna odlika potrošača danas. Mogućnost izbora, potpuna informisanost i prednost iskustvu u odnosu na posedovanje materijalnog učinili su da potrošači instinktivno donose većinu svojih kupovnih odluka i za kompanije budu nepredvidivi.

Programi lojalnosti predstavljaju jedan od najpopularnijih marketinških alata koje kompanije koriste za prikupljanje informacija, zadržavanje potrošača i unapređenje odnosa sa njima, kao i za stvaranje lojalnosti. Oni se danas koriste u brojnim privrednim delatnostima kao što su: maloprodajni lanci (supermarketi), apoteke, maloprodaja odeće i obuće, robne kuće, banke, avio kompanije, benzinske pumpe i sl. Po nekim procenama broj programa, kao njihovih članova svake godine uvećava.

Predmet istraživanja u ovom radu biće programi lojalnosti na benzinskim pumpama tj. kompanijama koje se bave maloprodajom nafte i naftinih derivata. Tržište nafte i naftinih derivata u Republici Srbiji liberalizovano je od 2011. godine. Međutim, i pored pored toga, zbog specifičnosti delatnosti, ona je uređena brojnim propisima što sve utiče na smanjeni manevarski prostor za diferenciranje, pa na kompanijama je težak zadatak da budu inovativni i drugačij. Program lojalnosti u ovom segment upravo predstavljaju način da se kompanija diferencira i potrošačima pruži veću vrednost, što je početak procesa izgradnje lojalnosti.

\section{Pojam lojalnosti}

Lojalnost je termin koji je relativno teško definisati. Različiti pojavni oblici i različiti načini njenog postizanja imali su za posledicu veliki broj objašnjenja. Lojalnost se obično definiše u kontekstu ponavljanja kupovnog procesa: „lojalnost kupaca je spremnost kupca da kupuje ili radi sa brendom iznova i iznova, i to je rezultat pozitivnog iskustva potrošača, njegovog zadovoljstva i vrednosti proizvoda ili usluga koje on transakcijom dobija“. ${ }^{1}$ Međutim, lojalnost potrošača je više od ponavljanja određenog kupovnog ponašanja, već predstavlja određenu povezanost koja ne mora da se odnosi na brend ili kompaniju, već i na ceni, ali i druge potrošače. ${ }^{2}$ Duboko usađena posvećenost da se u budućnosti stalno i često kupuje željeni proizvod i/li usluga, time uzrokujući ponovnu kupovinu istog, uprkos okolnostima i marketinškim naporima koji imaju potencijal da izazovu promenu ponašanja. ${ }^{3}$ Lojalnost potrošača se može definisati i kao kao spremnost bilo kog klijenta da kupi robu ili usluge kompanije u odnosu na konkurentne na tržištu. ${ }^{4}$ Nezavisno od načina na koji se definiše, lojalnost potrošača je rezultat pozitivnog emocionalnog iskustva koje proizilazi iz zadovoljstva zasnovanog na fizičkim atributima proizvoda ili karakteristikama usluge, percipirane vrednosti i iskustva vezanim za ranije potrošnju ili korišćenje. Drugim rečima, lojalnost opredeljuje buduće ponašanje koje je određeno ranijim iskustvom. Satisfakcija (zadovoljstvo) jeste osnov i bitan faktor za lojalnost, ali ne i jedini,

\footnotetext{
${ }^{1}$ S. Bernazzani (2018). Customer Loyalty: The Ultimate Guide, dostupno na: (https://blog.hubspot.com/service/customer-loyalty); posećeno 12.01.2019.

${ }^{2}$ Zikmund, William G.; McLeod Jr., Raymond; Gilbert, Faye W. (2003), Customer Relationship Management: Integrating Marketing Strategy and Information Technology, New York' John Wiley and Sons.

${ }^{3}$ Oliver, R.L (1999). Whence Consumer Loyalty?, Journal of Marketing, Vol. 63 (Special Issue 1999), op. cit. str. 34.

${ }^{4}$ Singh R. \& Khan I. (2012), "An Approach to Increase Customer Retention and Loyalty in B2C World", International Journal of Scientific and Research Publications, Volume2, Issue 6. op. cit. str. 1.
} 
jer ona predstavlja privremeno i pasivno stanje potrošača, na koje utiču percipirani kvalitet, svesnost i imidž brenda, dok je lojalnost emocionalne prirode, te zavisi od emocionalne vezanosti, poverenja, pouzdanosti. ${ }^{5}$

Lojalnost ima različite pojavne oblike. Kada se uzme u obzir definiciju da lojalnost predstavlja "privrženost marki ili preduzeću, koja se bazira na jakom pozitivnom stavu i ispoljava se stalnim ponavljanjem kupovine", odnosno stave u odnos dimenzije navedene u definicije:stav i ponašanje, izdvajaju se određene vrste lojalnosti. Rezultati odnosa ove dve dimenzije prikazani su na slici 1.

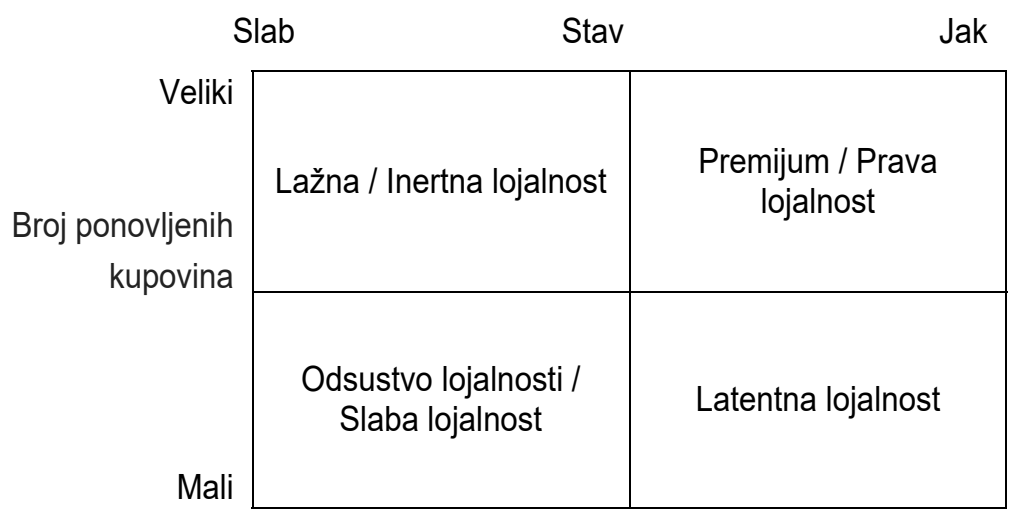

Slika 1 - Vrste lojalnosti

Izvor: Backman, S. J. and Crompton, J. L. (1991), „Differentiation between high, spurious, latent, and low loyalty participants in two leisure activities", Journal of Park and Recreation Administration, Vol. 9 No. 2, pp. 1-17.

Različiti intenziteti i odnosi dve dimenzije: stava i ponašanja za rezultat imaju četiri različita tipa lojalnosti:

1. Vrhunska lojalnost ili istinska lojalnost

2. Lojalnost prema inerciji ili lažna lojalnost.

3. Latentna lojalnost,

4. Nema lojalnosti ili niske lojalnosti

Vrhunska lojalnost ili istinska lojalnost postoji onda kada kod potrošača postoji visok nivo privrženosti i često ponavljanje kupovina. Lojalnost prema inerciji ili lažna lojalnost se javlja kada potrošač ima veliki broj ponovljenih kupovina, ali u osnovi toga ne leži emocionalna vezanost za proizvod ili kompaniju. Latentna lojalnost, postoji onda kada je kod potrošača postoji jaka emocionalna vezanost za proizvod ili kompaniju koju ne prati i adekvatno kupovno ponašanje. Odsustvo lojalnosti ili mala lojalnosti znači da nema emocionalne povezanosti i ponovne kupovine.

\footnotetext{
${ }^{5}$ Milisavljević M., Maričić B., i Gligorijević M. (2012). Osnovi marketinga (5. izdanje). Beograd: Centar za izdavačku delatnost Ekonomskog fakulteta Univerziteta u Beogradu, op. cit. str. 51.

${ }^{6}$ JSheth. N., B. Mittal, B. I. Newmann (1999). "Customer Behavior-Consumer Behavior and Beyond", The Dryden Press, Forth Worth, rr. 701.
} 


\section{Programi lojalnosti}

Kao što je rečeno „koncept lojalnosti potrošača razlikuje programe lojalnosti i lojalnost kompaniij odnosno brendu."

Dok je lojalnost prema kompaniji ili brendu određena emotivnim stanjem potrošača koji određuje privrženost i/ili pozitivnu emociju prema brendu ili kompaniji, programi lojalnosti predstavljaju pozitivan stav prema prednostima koje pružaju. Programi lojalnosti: su strukturirani marketinški napori koji nagrađuju, i stoga ohrabruju, lojalno ponašanje kupaca, koje je potencijalno korisno za firmu. ${ }^{8}$ Oni rade po principu podsticaja ili pogodnosti koje se ostvaruju na osnovu kumulativne kupovine tokom vremena. Konkretno, u marketingu maloprodaje to uključuje: kartice lojalnosti, kartice za nagrade, kartice za prikupljanje bodova ili klubske kartice koja identifikuju vlasnika kartice kao člana programa lojalnosti. ${ }^{9}$

Često se programi lojalnosti poistovećuju sa programima nagrađivanja, što je pogrešno. Za razliku od programa nagrađivanja, programi lojalnosti ohrabruju potrošače da pređu sa kratkoročnog ili jednokratnog odlučivanja na dinamično ili dugoročno donošenje odluka. Na taj način oni podstiču ponovnu kupovinu i rast stope zadržavanja. ${ }^{10}$ Programi lojalnosti se smatraju delom sveobuhvatne strategije odnosa sa potrošačima.

Programi lojalnosti nisu samo sredstvo za povećanje lojalnih kupaca organizacije, već i prilika za prikupljanje informacija o potrošačima, njihovim kupovnim navikama i preferencijama. Uz pomoć savremene informacione tehnologije, a na osnovu prikupljenih podataka, proizvođači, ali i maloprodavci i drugi pružaoci usluga u mogućnosti su da svojim potrošačima ili klijentima pruže potpuno kastomizovani proizvod ili uslugu, odnosno pogodnosti samog programa. Baze podataka su te koje su omogućile da se upoznaju potrošači njihove kupovne navike i nagrade oni koji manifestuju željeno ponašanje.

Programi lojalnosti nisu svemogućni. Oni neće dati pozitivne rezultate za proizvode i usluge koji nisu prihvaćeni od strane potrošača odnosno ne pružaju očekivani nivo satisfakcije. Međutim, nemaju ni svi potrošači potencijal da budu lojalni. Programi lojalnosti daju rezultate samo u slučaju lojalnih ili potencijalno lojalnih potrošača. To podrazumeva procesu implementacije treba da prethodi sprovođenje procesa segmentacije kako bi se identifikovale grupe potrošača na koje treba usmeriti programe lojalnosti. Uspešni programi lojalnosti trebalo bi da budu dizajnirani u skladu sa sledećim pravilima: ${ }^{11}$

1. Privući kupce koji će najverovatnije ponoviti kupovinu.

2. Identifikovati potrošače koji najverovatnije neće ponoviti kupovati i u skladu sa tim redukovati marketing troškove za ovaj segment.

3. Usredsredite marketinški budžet na one koji nisu obavili drugu kupovinu, ali imaju isti profil kao postojeći potrošači koji su ponovili kupovinu.

\footnotetext{
${ }^{7}$ Evanschitzky, H., Ramaseshan \& David M. Woisetschläger \& Verena Richelsen \& Markus Blut \& Christof Backhaus. (2012). Consequences of customer loyalty to the loyalty program and to the company, Journal of the Academy of Marketing Science, 40:625-638, DOI 10.1007/s11747-011-0272-3. pp. 626.

${ }^{8}$ Sharp, B. and Sharp A., (1997). "Loyalty Programs and their Impact on Repeat-purchase Loyalty Patterns", International Journal of Research in Marketing, Vol 14, No. 5, p. 474, 473-486.

${ }^{9}$ Singh R. \& Khan I. (2012), "An Approach to Increase Customer Retention and Loyalty in B2C World", International Journal of Scientific and Research Publications, Volume 2, Issue 6. op. cit. str. 1.

${ }^{10}$ Lewis, M. (2004). The Influence of Loyalty Programs and Short-Term Promotions on Customer Retention Journal of Marketing Research 281 Vol. XLI (August 2004), 281-292.

${ }^{11}$ Clark Peter (2010), "The 15 Business Benefits of a Loyalty Initiative”, The Wise Marketer.
} 


\section{Vrste programa lojalnosti}

Uspeh određenog programa lojalnosti zavisi od velikog broja faktora: odabir adekvatne ciljne grupe, karakteristika poslovnog okruženja, stepena diferencijacije, konkurentske pozicije preduzeća. U literaturi iz ove oblasti mogu se pronaći brojne klasifikacije programa lojalnosti. Osnov za većinu kategorizacija su način ostvarivanja članstva ili način nagrađivanja. Kada je u pitanju forma članstva razlikuju se dve različite vrste programa lojalnosti: zatvoreni i otvoreni. ${ }^{12}$

Zatvoreni program lojalnosti podrazumevaju da svako ko želi da učestvuje u program lojalnosti mora da prođe određenu formalnu proceduru učlanjenja. Učlanjenje može da uključuje jednokratnu uplatu prilikom učlanjena ili preuzimanje obaveze plaćanja godišnje članarine i popunjavanje pristupnice. Postoje slučajevi da članstvo bude uslovljeno i na neki drugi način (obim kupovine, vrsta kupovine, različite vrste pretplata i sl.). Ovakva vrsta programa lojalnosti omogućuje da se program lojalnosti učlane samo potrošači koji po svojim karakteristikama odgovaraju unapred determinisanoj ciljnoj grupi.

Nasuprot zatvorenim, u otvorene programe se može učlaniti svaki zainteresovani potrošač. Ovakvi program obično ne predviđaju neku formalnu procedure učlanjenja. Karakteristike oba programa navedene su u tabeli 1.

Tabela 1 - Karakteristike zatvorenih i otvorenih programa lojalnosti

\begin{tabular}{|l|l|}
\hline Članarina je u funkciji pokrivanja troškova & Dostupan je daleko većem broju potrošača \\
\hline $\begin{array}{l}\text { Zahtev za članstvo olakšava fokus na određene } \\
\text { ciljne grupe }\end{array}$ & Baza podataka je kompletnija \\
\hline Ograničeni pristup čini članstvo još vrednijim & $\begin{array}{l}\text { Potencijalne potrošače ili potrošače konkurentskih } \\
\text { proizvoda lakše je privući }\end{array}$ \\
\hline $\begin{array}{l}\text { Jasno definisana struktura članstva čini } \\
\text { komunikaciju efikasnijom }\end{array}$ & $\begin{array}{l}\text { Kompletiranje baze podataka i dalja analiza mogu } \\
\text { da omoguće segmentaciju i komunikaciju koja je } \\
\text { prilagođena svakom pojedinačnom segmentu }\end{array}$ \\
\hline $\begin{array}{l}\text { Zahtev za članstvo održava broj članova, a time } \\
\text { smanjuje i troškove }\end{array}$ & $\begin{array}{l}\text { Veći broj članova pomaže da se postigne kritična masa, } \\
\text { koja čini da programi lojalnosti budu troškovno efikasniji. }\end{array}$ \\
\hline $\begin{array}{l}\text { Baza podataka uključuje samo članove koji imaju } \\
\text { natprosečno interesovanje za proizvod }\end{array}$ & \\
\hline $\begin{array}{l}\text { Plaćeno članstvo podiže očekivanja, tako da se } \\
\text { programima lojalnosti upravlja na način koji } \\
\text { neprestano insistira na podizanju vrednosti. }\end{array}$ & \\
\hline
\end{tabular}

U odnosu na vrstu nagrade razlikuju se programi lojalnosti sa novčanim nagradama i programi lojalnosti sa nagradama u formi posebnih tretmana ${ }^{13}$ ili programi lojalnosti sa opipljivim i neopipljivim nagradama. ${ }^{14}$ Posmatrajući u širem kontekstu programi lojalnosti mogu biti kategorizovani: u odnosu na njihovu povezanost sa proizvodom ili brendom direktni i indirektni ili u odnosu na vrednost: luksuzna ili obična nagrada.

\footnotetext{
${ }^{12}$ S. A. Butscher (2016). Customer Loyalty Programmes and Clubs, 2nd Edition, Abingdon: Routledge; pp. 50.

${ }^{13}$ Furinto, A., Pawitra, T. and Balqiah, T.E. (2009). Designing competitive loyalty programs: how types of program affect customer equity. Journal of Targeting, Measurement and Analysis in Marketing, 17, pp. 307-319.

${ }^{14}$ Roehm, M. L., E. B. Pullins, and H. A. Roehm Jr. 2002. Designing loyalty building programs for packaged goods brands. Journal of Marketing Research 39: 202-13.
} 
$U$ najosnovnijoj formi razlikuju se četiri široke kategorije programa lojalnosti. ${ }^{15} \mathrm{U}$ tabeli 2 dat je sumarni prikaz osnovnih karakteristika svakog tipa programa lojalnosti.

Tabela 2 - Četiri osnovna tipa programa lojalnosti

\begin{tabular}{|l|l|}
\hline \multicolumn{1}{|c|}{ Vrsta programa } & \multicolumn{1}{c|}{ Karakteristike programa } \\
\hline Tip 1: & $\begin{array}{l}\text { - Članstvo je otvoreno za sve potrošače } \\
\text { - Zaposleni će odobriti popust čak ako član zaboravi ili ne- } \\
\text { ma karticu; } \\
\text { - Svaki član dobija isti popust bez obzira na istoriju kupo- } \\
\text { članovi primaju dodatni popust na kasi } \\
\text { - Firma nema bazu podataka o kupcima, njihovim demo- } \\
\text { grafskim karakteristikama ili istoriji kupovine; } \\
\text { - Ne postoji ciljana komunikacija usmerena ka članovima } \\
\text { programa lojalnosti. }\end{array}$ \\
\hline $\begin{array}{l}\text { Tip 2: } \\
\text { Članovi dobijaju jedan proizvod besplatno } \\
\text { kada kupe određen broj jedinica tog istog } \\
\text { proizvoda }\end{array}$ & $\begin{array}{l}\text { - Članstvo je otvoreno za sve potrošače; } \\
\text { - Preduzeće ne održava bazu podataka potrošača u smi- } \\
\text { slu povezivanja kupovine sa određenim potrošačima. }\end{array}$ \\
\hline $\begin{array}{l}\text { Tip 3: } \\
\text { Članovi ostvaruju popust na osnovu } \\
\text { prikupljenih bodova tokom više kupovina }\end{array}$ & $\begin{array}{l}\text { - Od potrošača, članova programa se očekuje da potroše } \\
\text { očekivani iznos kako bi se kvalifikovali za popust. }\end{array}$ \\
\hline Tip 4: & $\begin{array}{l}\text { - Članovi su podeljeni na segmente na osnovu njihove } \\
\text { istorije kupovine } \\
\text { Članovi dobijaju ciljane ponude i e-poruke } \\
\text { Zahteva sveobuhvatnu bazu podataka članova sa njiho- }\end{array}$ \\
\hline
\end{tabular}

Izvor: Berman, B. (2006). Developing an Effective Customer Loyalty Program, California Management Review, Vol. 49, No. 1, op. cit. str.125.

Uzimajući sve prethodno u programe lojalnosti koje se najčešće primenjuju u praksi možemo sistematizovati na sledeći način: ${ }^{16}$

- Sistem prikupljanja bodova;

- Sistem nivoa;

- Programi lojalnosti sa plaćanjem unapred za VIP beneficije;

- Programi lojalnosti koji uključuju partnerstvo sa drugim kompanijama koja potrošačima pruža zaokruženu ponudu;

- Programi kartica lojalnosti;

- Programi lojalnosti za redovne kupce;

- Poklon kartice ili sertifikati;

- Politika vraćanja za lojalne potrošače;

- Povraćaj novca za lojalne potrošače;

- Popusti koji se odobravaju tokom vremena;

- Prodaja u paketu.

${ }^{15}$ Berman, B. (2006). Developing an Effective Customer Loyalty Program, California Management Review, Vol. 49, No. 1, op. cit. str. 124.

${ }^{16}$ Magatef , S., G. \& Tomalieh, E., F.(2015). The Impact of Customer Loyalty Programs on Customer Retention, International Journal of Business and Social Science, Vol. 6, No. 8(1), op. cit. str. 80-81. 
Sistem prikupljanja bodova predstavlja model programa lojalnosti koji se prilično često sreće u praksi i koji funkcioniše po principu prikupljanja bodova koje potrošači dobijaju prilikom svake obavljene kupovine. Prikupljene bodove potrošači članova mogu da razmene za odgovarajuću nagradu. Sistem nivoa projektovan je tako da se od potrošača koji su članovi programa očekuje kontinuitet u obavljanju kupovina. Na samom početku, prilikom učlanjenja potrošačima se pruža simbolična nagrada za obavljenu kupovinu, ali im je predočeno da sa intenziviranjem kupovina i nagrade će biti veće. Drugim rečima, svaki pomak na više lestvici lojalnosti biće dodatno nagrađen i na taj način se potrošači stimulišu da više kupuju. Programi lojalnosti sa plaćanjem unapred za VIP beneficije predviđaju jednokratnu naplatu potrošačima za učlanjenje u program lojalnosti i početak prikupljanja bodova. Svrha naplate je povlašćen tretman potrošača i izbegavanje eventualnih problema prilikom narednih kupovina. Programe lojalnosti koji uključuju partnerstvo sa drugim kompanijama koja potrošačima pruža zaokruženu ponudu pokreću kompanije koje svoje lojalne potrošače žele da nagrade na način koji prevazilazi njihove objektivne kapacitete. Analizirajući svoje potrošače, njihov životni stil i kupovne navike kompanije pronalaze druge kompanije koje bi se dobro uklopile kao partneri u sistemu nagrađivanja lojalnih potrošača. Programi kartica lojalnosti je plan podsticaja koji omogućava maloprodaji da prikuplja informacije o kupcima i njihovim kupovinama. Kupcima se nude popusti na proizvode, kuponi, bodovi ili neka druga nagrada u zamenu za njihovo dobrovoljno učešće u programu. Programi lojalnosti za redovne kupce su dizajnirani tako da obično trgovci nude određene simbolične besplatne usluge kupcima, ali samo ako broj kupovina ili ukupan iznos kupovine dostigne određeni limit. Ovako postavljena pravila programa motivišu kupce da obim kupovine ili ukupna nabavna vrednost budu u skladu sa limitom i na taj način ostvare nagradu. Na duži rok, ova vrsta programa lojalnosti povećava prodaju i stvara lojalne potrošače. Poklon kartice ili vaučeri predstavljaju program lojalnosti koji su uveli trgovci. Problem kod ove vrste programa je što se ne može predvideti da li će kupac iskoristi poklon karticu ili vaučer i da li će to uraditi neko drugi umesto njega. Uz raspoloživu količinu poklon kartice kupac će kupiti proizvode ili platiti usluge u iznosi koji nadmašuje vrednost koja je naznačena na kartici ili vaučeru i na taj način povećati prodaju. Politika vraćanja za lojalne potrošače je program koji lojalnim potrošačima pruža benefite u slučajevima kada nisu zadovoljni obavljenom kupovinom ili su se predomislili. Pogodnost se prevashodno odnosi na produženi rok za povraćaj kupljenog proizvoda, nego što je to uobičajeno. Povraćaj novca za lojalne potrošače je program koji podrazumeva povraćaj određenog procenta od ukupno utrošenog u određenom periodu. Varijetet prethodnom programu lojalnosti je su i programi koji popuste koji se vremenom odobravaju. Prodaja u paketu je program lojalnosti gde trgovac pored osnovnog proizvoda prodaje i druge proizvode bez dodatnih troškova.

Programi lojalnosti, zbog velikog broja elemenata koji mogu da utiču na njih, mogu se podeliti na tri kategorije: ${ }^{17}$

1. programi štednje

2. klub programi

3. programi marketinga odnosa

\footnotetext{
${ }^{17}$ Peelen E. (2005). “Customer Relationship Management", Prentice Hall, Harlow, rr. 175.
} 
Programi štednje, po svojoj prirodi ne predstavljaju prave programe lojalnosti. Fokus je na ohrabrivanju potrošača da čine transakcije, nagrađujući ih za kupovine koje su ranije obavili. Nagrade su obično u obliku bodova, bonusa ili prikladnog poklona.

Klub programi, pružaju mogućnost potrošačima da postanu članovi kluba, besplatno ili uz neku minimalnu naknadu. Po učlanjivanju potrošač dobija karticu koja pruža mogućnost da sebe identifikuje kao učesnika. Kartice mogu biti različite, od kartica distributera koje pružaju određene kreditne mogućnosti do sponzorskih kreditnih kartica. Prednosti ovog programa su još i u publikacijama koje objavljuje preduzeće, popustima, načinima plaćanja.

Tabela 3 - Kategorije programa lojalnosti

\begin{tabular}{|c|c|c|c|c|}
\hline Vrsta & Početak & Komunikacija & Cilj & Podsticaj \\
\hline $\begin{array}{l}\text { Programi } \\
\text { štednje }\end{array}$ & $\begin{array}{l}\text { Obavljanje } \\
\text { kupovne } \\
\text { transakcije }\end{array}$ & $\begin{array}{l}\text { Usmerena je ka } \\
\text { bonusima i } \\
\text { poklonima }\end{array}$ & $\begin{array}{l}\text { Ponašanje } \\
\text { potrošača koje } \\
\text { karakterišse } \\
\text { povećanje } \\
\text { potrošnje; } \\
\text { zadržavanje } \\
\text { potrošača }\end{array}$ & $\begin{array}{l}\text { Pokloni ili nagrade } \\
\text { koje se dodatno } \\
\text { plaćaju, a povezane } \\
\text { su sa proizvodom }\end{array}$ \\
\hline $\begin{array}{l}\text { Klub } \\
\text { programi }\end{array}$ & $\begin{array}{l}\text { Potrošači se } \\
\text { moraju } \\
\text { registrovati; } \\
\text { uslovi pod } \\
\text { kojima je neko } \\
\text { primljen u } \\
\text { članstvo su } \\
\text { različiti (ranije } \\
\text { kupovine, } \\
\text { plaćanje } \\
\text { određenih } \\
\text { doprinosa) }\end{array}$ & $\begin{array}{l}\text { Usmerena je ka } \\
\text { proizvodu } \\
\text { (brendu) ili } \\
\text { poenima }\end{array}$ & $\begin{array}{l}\text { Povećanje } \\
\text { povezanosti } \\
\text { potrošača sa } \\
\text { brendom i/lil } \\
\text { ponuđačem; } \\
\text { dugoročna } \\
\text { odanost sa } \\
\text { potrošačima i } \\
\text { ujedno više } \\
\text { ponovljenih } \\
\text { kupovina }\end{array}$ & $\begin{array}{l}\text { Informacije (časopisi), } \\
\text { mogući popusti, } \\
\text { osiguranje, kredit, } \\
\text { garancije i sl. }\end{array}$ \\
\hline $\begin{array}{l}\text { Programi } \\
\text { marketinga } \\
\text { odnosa }\end{array}$ & $\begin{array}{l}\text { Minimum broja } \\
\text { transakcija }\end{array}$ & $\begin{array}{c}\text { Usmerena je ka } \\
\text { obrascima } \\
\text { ponašanja } \\
\text { potrošača, } \\
\text { bonusima i } \\
\text { poklonima }\end{array}$ & $\begin{array}{l}\text { Povećanje } \\
\text { međusobne } \\
\text { povezanosti } \\
\text { između ponuđača } \\
\text { i potrošača; } \\
\text { dugoročna } \\
\text { odanost sa } \\
\text { potrošačima i } \\
\text { ujedno više } \\
\text { ponovljenih } \\
\text { kupovina }\end{array}$ & $\begin{array}{l}\text { Komplementarni } \\
\text { proizvodi i usluge, } \\
\text { uključujući i magazine } \\
\text { namenjene } \\
\text { potrošačima, } \\
\text { savetovanje, } \\
\text { servisiranje, popusti } \\
\text { itd. }\end{array}$ \\
\hline
\end{tabular}

Izvor: E. Peelen: “Customer Relationship Management", Prentice Hall, Harlow, 2005, str. 175.

Treći nivo su programi marketinga odnosa koji predstavljaju prave programi lojalnosti. Polazna tačka ovog programa je ojačavanje povezanosti između ponuđača i potrošača. Ponuđači koriste položaj potrošača, i kroz strukturalnu upotrebu određenih marketing alata, rade na povećanju odanosti i ponašanja u kupovini na dugi rok. Učesnici u ovom programu često se mogu identifikovati karticama, tako da se svaka interakcija može registrovati na individualnom nivou. 


\section{Programi lojalnosti u maloprodaji nafte i naftinih derivata}

Prema podacima Agencije za energetiku do kraja 2018. godine izdata je 461. licenca za trgovinu motornim i drugim gorivima na stanicama za snabdevanje prevoznih sredstava. ${ }^{18}$ Paretova pravilo 20:80 najbolje objašnjava strukturu tržišta maloprodaje nafte i naftinih derivata u Republici Srbiji: veliki broj malih učesnika i mali broj kompanija sa većim tržišnim učešćem. Procena je da većina vlasnika licenci u svom vlasništvu ima jedan ili dva prodajna objekta. Liberalizacija tržište nafte i naftinih derivata omogućila je slobodu izbora dobavljača, ali i mogućnost da se ovom delatnošću bave svi koji ispune uslove regulisane zakonskim propisima. Propisi koji regulišu ovu oblast su: ${ }^{19}$

- Zakon o energetici,

- Zakon o trgovini,

- Uredba o obeležavanju (markiranju) derivata nafte

- Uredba o monitoringu kvaliteta derivata nafte i bio goriva;

- Pravilnik o licenci za obavljanje energetske delatnosti i sertifikaciji;

- Pravilnik o tehničkim i drugim zahtevima za tečna goriva naftnog porekla;

- Pravilnik o minimalnim tehničkim uslovima za obavljanje trgovine derivatima nafte i bio gorivima i Pravilnik o izmeni i dopunama

- Pravilnik o minimalnim tehničkim uslovima za obavljanje trgovine derivatima nafte i bio grivom.

- Uredba o visini, načinu obračuna, plaćanje i raspolaganja naknadom za formiranje obaveznih rezervi nafte i derivata nafte

Za potrebe istraživanja analizirani prodavci nafte i naftinih derivata koji imaju deset ili više prodajnih objekata (benzinskih pumpi). Spisak kompanija koje su bile predmet istraživanja i broj pumpi prikazani su u tabeli 4.

Tabela 4 - Vodeće kompanije koje se bave maloprodajom nafte i naftinih derivata i broj pumpi

\begin{tabular}{|c|l|c|}
\hline R. br. & \multicolumn{1}{|c|}{ Kompanija } & Broj pumpi \\
\hline 1. & EKO pumpe & 55 \\
\hline 2. & EURO petrol & 30 \\
\hline 3. & Knez petrol & 90 \\
\hline 4. & LUKOIL & 117 \\
\hline 5. & MOL & 63 \\
\hline 6. & Nafthem petrol & 11 \\
\hline 7. & NIS & 317 \\
\hline 8. & OMV & 61 \\
\hline 9. & Petrol & 13 \\
\hline 10. & Radun AVIA & 24 \\
\hline
\end{tabular}

\footnotetext{
${ }^{18}$ Agencija za energetiku Republike Srbije. Opširnije onlajn: https://www.aers.rs/Index.asp?|=1\&a=535\&ed=21\&id_ed=65\&sid=1\&tp=Zanpra

${ }^{19}$ Komisija za zaštitu konkurencije (2018). Izveštaj o sektorskoj analizi tržišta trgovine na malo derivatima nafte u 2017. godini, decembar (2018), str. 10-11.
} 
Iz tabele 4 lako se može uočiti da najveći broj pumpi ima kompanija Naftna industrija Srbije (NIS), ukupno 317. Mora se naglasiti da su u ovu brojku uključene i Gazprom pumpe koje predstavljaju premijum brend NIS-a i na teritoriji Republike Srbije posluju od 2012. godine. Procentualno učešće na tržištu prikazano je na grafikonu 1.

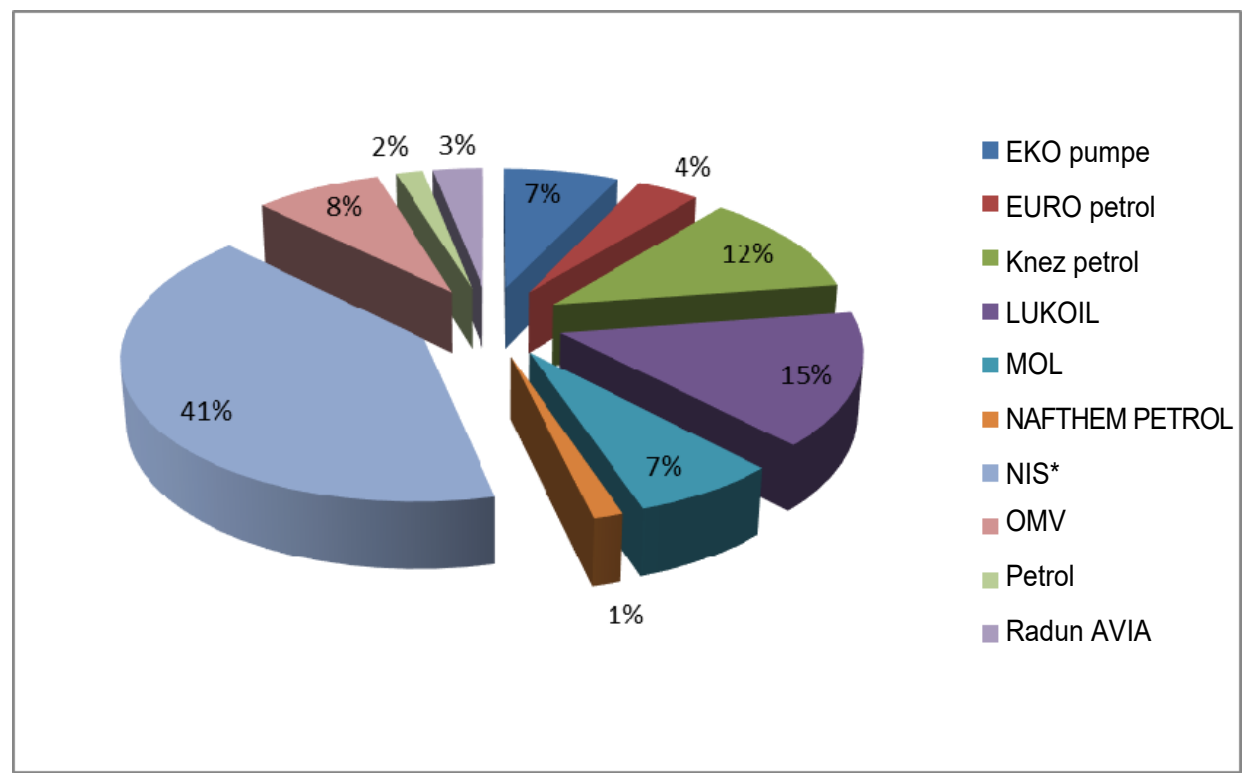

Grafikon 1 - Procentualni tržišno učešće analiziranih kompanija

Mora se imati u vidu dana navedeni procenti predstavljaju trenutnu situaciju na tržištu koja se brzo menja, jer prema najavama kompanija Shell i Coral S.A. u Srbiji planiraju otvaranje 80 benzinskih pumpi pod brendom Shell.

\section{Programi lojalnosti u maloprodaju nafte i naftinih derivata}

Svesne visokog stepena konkurencije i stanja na tržištu, kompanije iz ove oblasti neprekidno rade na pronalaženju modela prodaje i pružanja usluga koja će krajnjim potrošačima pružiti veću vrednost, a sabi bolju tržišnu poziciju. Jedan od načina da se to postigne jeste primena programa lojalnosti na način koji u sebi inkorporira inovativnost i pozitivna poslovna iskustva iz oblasti dizajnirana programa lojalnosti. 
Tabela 5 - Tipovi programa lojalnosti

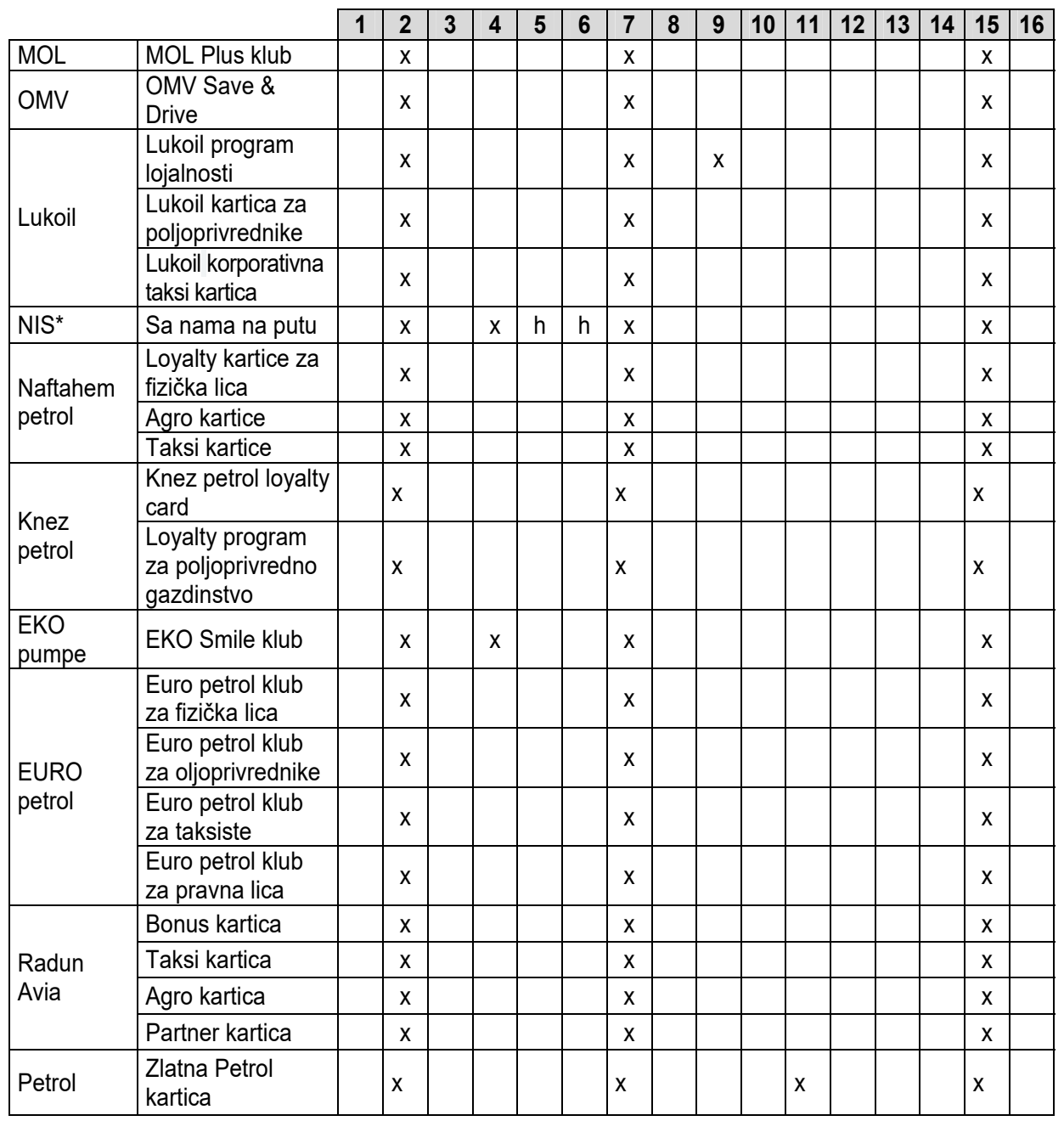

Legenda:

1. Otvoreni

2. Zatvoreni

3. Sistem prikupljanja bodova;

4. Sistem nivoa;

5. Programi lojalnosti sa plaćanjem unapred za VIP beneficije;

6. Programi lojalnosti koji uključuju partnerstvo sa drugim kompnaijama koja potrošačima pruža zaokruženu ponudu;
7. Programi kartica lojalnosti;

8. Programi lojlanosti za redovne kupce;

9. Poklon kartice ili vaučeri

10. Politika vraćanja za lojalne potrošače;

11. Povraćaj novca za lojalne potrošače;

12. Popusti koji se odobravaju tokom vremena;

13. Prodaja u paketu

14. Programi štednje

15. Klub programi

16. Programi marketinga odnosa 
Programi lojalnosti koje primenjuju kompanije koje se bave maloprodajom nafte i naftinih derivata kategorisane su na osnovu dve opšte tipologija i jedne detaljne. Opšte tipologije se odnose na vrstu članstva (otvoreni i zatvoreni programi lojalnosti) i prirodu programa lojalnosti (Programi štednje, Klub programi i Programi marketinga odnosa). Detaljna tipologija uvažava specifičnosti različitih modela programa lojalnosti i prepoznaje 11 varijeteta. Mora se naglasiti da različite tipologije predstavljaju sistematizaciju različitih formi programa lojalnosti koja omogućuje određena preklapanja.

Sve kompanije koje se bave maloprodajom nafte i naftinih derivata odabrale su programe lojalnosti kao svoje strateško opredeljenje, nezavisno od tržišnog učešća, veličine kompanije ili geografske rasprostranjenosti,. Neke kompanije, uvažavajući specifične potrebe za gorivom, kreirale su posebne programe lojalnosti za različite ciljne grupe. Prevashodno se to odnosi na programe koji su namenjeni fizičkim licima i programe lojalnosti koji su namenjeni pravnim licima. Programi lojalnosti za fizička lica osmišljeni su tako da članovi programa za svoju lojalnost budu nagrađeni popustima, nagradama, poklonima. U suštini programa za pravna lica jeste racionalnost i ekonomičnost. Korisnicima iz ovog segmenta pruža se čitav spektar različitih pogodnosti: usluge održavanja voznog parka, odloženog plaćanja, plaćanja preko računa, vođenja evidencije o mesečnoj potrošnji za svaki automobil u voznom parku, što za preduzeće predstavlja olakšicu u praćenju i kontroli troškova.

Određene kompanije sprovele su dodatnu segmentaciju i u odnosu na to kreirale posebne programe lojalnosti za poljoprivrednike i za taksiste. Uvažavajući specifične potrebe za gorivom - vrstama, količinama, a za poljoprivrednike i sezonom, pet kompanija ima programe lojalnosti za poljoprivrednike (Lukoil, Nafthem petrol, Knez petrol, Euro petrol, Radun Avia), dok su četiri za taksi vozače (Lukoil, Nafthem petrol, Euro petrol, Radun Avia).

Analizirajući programe lojalnosti koje maloprodavci nafte i naftinih derivata u Republici Srbiji po svojim karakteristikama ne mogu se svrstati u određeni specifičan teorijski model, jer većina njih prevazilazi teorijski definisane granice odnosno, u sebi inkorporiraju karakteristike dva ili više različitih tipova programa lojalnosti. Najbolji primer za to je program lojalnosti "Sa nama na putu" Naftne industrije Srbije (NIS) koji je dizajniran tako da članovi omogućuje da prilikom svake kupovine goriva, roba i usluga prikupe određen broj bodova koje mogu da iskoriste prilikom neke od narednih kupovina. $U$ tom pogledu ovaj program lojalnosti spada u klub programe i programe kartica lojalnosti. Međutim, obim potrošnje kategorizuje članove u tri nivoa: srebrni, zlatni i platinasti. Veća potrošnja omogućuje članovima da se kvalifikuju za prelazak na viši nivo i veće pogodnosti. U tom kontekstu, ovaj program možemo svrstati u programe koji članove stratifikuje u više nivoa. Slično dizajniran program ima i kompanija Eko koji u okviru svog Eko smajl programa predviđa premijum status za potrošače koji troše više. Pored toga, u saradnji sa Sber bankom NIS je članovima programa pružio mogućnost da kupljene proizvode i usluge plate odloženo do 45 dana. Međutim, kartica lojalnosti nije klasična sponzorska kreditna kartica, pošto je plaćanje omogućeno samo na NIS i Gazprom benzinskim pumpama. Ova pogodnost mesečno članove košta 99 dinara i po ova dva osnova program lojalnosti ima karakteristike: Programi lojalnosti sa plaćanjem unapred za VIP beneficije i Programi lojalnosti koji uključuju partnerstvo sa drugim kompanijama koja potrošačima pruža zaokruženu ponudu. Brojne promotivne aktivnosti koje su vremenski oročene predstavljaju dodatne pogodnosti za članove. 
Sve kompanije su se opredelile za zatvoreni program lojalnosti, što podrazumeva obavezno učlanjenje u smislu popunjavanja određenog obrasca, odnosno ostavljanja traženih podataka. Samo dve kompanije su uslovile učlanjen kupovinom određene količine goriva ili određenom potrošnjom (Lukoil, Petrol).

\section{Zaključak}

Tržište maloprodaje nafte i naftinih derivate u Republici Srbiji se najbolje može opisati Paretovim principom 20:80. Veliki broj malih učesnika sa jedne stane (kompanije sa par benzinskih pumpi) i mali broj velikih kompanija s brojnim pumpama koje su geografski pravilno raspoređen. Isti princip se može primeniti i u grupi najvećih kompanija, koje su bile predmet analize u ovom radu. Međutim, nezavisno od veličine kompanije i tržišnog učešća sve kompanije kao stratešku opciju odabrale su primenu programa lojalnosti kao način da privuku nove i zadrže postojeće potrošače i na taj način poboljšaju svoju tržišnu poziciju.

Činjenica da su se sve kompanije opredelile za zatvorene programe lojalnosti, ukazuje na to da su uvidele značaj informacija o kupcima u pogledu kastomizacije i unapređenja ponude. Program lojalnosti koji su bili predmet analize po svojim karakteristikama odstupaju od određenih teorijski definisanih tipova programa lojalnosti, što ukazuje na činjenicu da su prilikom njihovog dizajnirana imao u vidu širi obuhvat. Oni predstavljaju odraz karakteristika tržišta, kupovnog ponašanja i kupovne moći potrošača, pozicije kompanije na tržištu i geografske rasprostranjenosti prodajnih objekata. Kompanije su članovima pružile punu tehničku podršku (kontakt centri, besplatne telefonske linije, online podrška), a neke su kreirale i mobilne aplikacije sve sa ciljem da se olakša uvid u stanje.

Interesantno je da i kompanije sa dominantnom pozicijom na tržištu nisu zanemarile značaj programa lojalnosti govori o dinamičnim promenama koje vladaju na tržištu, ali i značaju koji programi imaju na rezultate poslovanja.

Na kraju treba naglasiti da programi lojalnosti nisu svemogući: loš proizvod ili lošu uslugu, nezadovoljstvo potrošača ne može da anulira ni jedan program lojalnosti, ma kakve pogodnosti davao svojim članovima.

\section{Literatura}

[1] Backman, S. J. and Crompton, J. L. (1991), „Differentiation between high, spurious, latent, and low loyalty participants in two leisure activities", Journal of Park and Recreation Administration, Vol. 9, No. 2, pp. 1-17.

[2] Berman, B. (2006). Developing an Effective Customer Loyalty Program, California Management Review, Vol. 49, No. 1.

[3] Bernazzani, S. (2018). Customer Loyalty: The Ultimate Guide, dostupno na: (https://blog.hubspot.com/service/customer-loyalty); posećeno 12.01.2019.

[4] Butscher, S. A. (2016). Customer Loyalty Programmes and Clubs, 2nd Edition, Abingdon: Routledge.

[5] Clark, P. (2010), „The 15 Business Benefits of a Loyalty Initiative“, The Wise Marketer.

[6] Zikmund, William G.; McLeod Jr., Raymond; Gilbert, Faye W. (2003), Customer Relationship Management: Integrating Marketing Strategy and Information Technology, New York' John Wiley and Sons. 
[7] Komisija za zaštitu konkurencije (2018). Izveštaj o sektorskoj analizi tržišta trgovine na malo derivatima nafte u 2017. godini, decembar (2018), str. 10-11.

[8] Lewis, M. (2004). The Influence of Loyalty Programs and Short-Term Promotions on Customer Retention Journal of Marketing Research 281 Vol. XLI (August 2004), 281-292.

[9] Magatef , S., G. \& Tomalieh, E., F.(2015). The Impact of Customer Loyalty Programs on Customer Retention, International Journal of Business and Social Science, Vol. 6, No. 8(1), 78-93.

[10] Milisavljević M., Maričić B., i Gligorijević M. (2012). Osnovi marketinga (5. izdanje). Beograd: Centar za izdavačku delatnost Ekonomskog fakulteta Univerziteta u Beogradu, op. cit. str. 51.

[11] Oliver, R.L (1999). Whence Consumer Loyalty?, Journal of Marketing, Vol. 63 (Special Issue 1999), op. cit. str. 34.

[12] Peelen, E. (2005). "Customer Relationship Management", Prentice Hall, Harlow

[13] Roehm, M. L., E. B. Pullins, and H. A. Roehm Jr. 2002. Designing loyalty building programs for packaged goods brands. Journal of Marketing Research 39: 202-13.

[14] Sharp, B. and Sharp A., (1997). "Loyalty Programs and their Impact on Repeat-purchase Loyalty Patterns", International Journal of Research in Marketing, Vol 14, No. 5, 473-486.

[15] Sheth. N. J, B. Mittal, B. I. Newmann (1999). "Customer Behavior - Consumer Behavior and Beyond", The Dryden Press, Forth Worth, rr. 701.

[16] Singh R. \& Khan I. (2012), "An Approach to Increase Customer Retention and Loyalty in B2C World", International Journal of Scientific and Research Publications, Vol. 2, Issue 6.

[17] Furinto, A., Pawitra, T. and Balqiah, T. E. (2009). Designing competitive loyalty programs: how types of program affect customer equity. Journal of Targeting, Measurement and Analysis in Marketing, 17, pp. 307-319.

[18] Agencija za energetiku Republike Srbije. Opširnije onlajn: https://www.aers.rs/Index.asp?!=1\&a=535\&ed=21\&id_ed=65\&sid=1\&tp=Zanpra 